\title{
KEARIFAN LOKAL MASYARAKAT KAMPUNG IDIOT DALAM UPAYA MENGEMBALIKAN DAERAH ALIRAN SUNGAI DAN SUMBER MATA AIR DUKUH SIDOWAYAH DESA SIDOHARJO KECAMATAN JAMBON KABUPATEN PONOROGO
}

\author{
Fuad Fitriawan
}

\begin{abstract}
ABSTRAK
Kampung Idiot merupakan julukan bagi suatu daerah atau kampung yang masyarakatnya menyandang Idiot sebagian besar atau sebagian kecil, diantaranya adalah Dusun Sidowayah yang terletak di Desa Sidoharjo Kecamatan jambon Ponorogo, secara geografis letah dusun sidowayah sangat terpencil, jauh dari akses keluar dan jalan menuju ke sana juga relatif sulit. Hingga sat ini permasalahan rumit mereka hadapi diantaranya sulitnya memperoleh air dari sumber mata air dan DAS, terlebih di musim kemarau. Akibat adanya permasalahan tersebut banyak warga yang tidak dapat memanfaatkan sawah dan ladangnya jika msuim kemarau tiba. Beberapa warga mencoba mencari jalan keluar permasalahan tersebut dengan membuat program bertajuk kearifan lokal yang dipelopori oleh FSB. Adapun rumusan masalah penelitian ini meliputi tiga aspek yaitu adanya kearifan lokal di Dusun Sidowayah, bentuk-bentuk kerifan lokal di Dusun tersebut dan kemanfaatannyaterhadap warga dusun sidowayah. Adapun hasil penelitiannya Bentuk kearifan lokal di Dusun Sidowayah dalam upaya mengembalikan Daerah Aliran Sungai dan Sumber Mata Air lebih banyak dilakukan dalam kegiatan kemasyarakatan yang diorganisasikan oleh satu organisasi pemuda yaitu Forum Sidowayah Bangkit.Program kegiatan masyarakat sebagai bentuk kearifan lokal dalam upaya mengembalikan Daerah Aliran Sungai dan Sumber Mata Air di Dusun Sidowayah di antaranya berupa Program Penghijauan, Program Pipanisasi, dan Program Pendidikan Lingkungan Hidup. Belum terlihatnya kemanfaatan program dari Forum Sidowayah Bangkit khususnya untuk masyarakat Sidowayah disebabkan beberapa faktor kendala, yakni adanya perilaku atau kebiasaan kurang baik warga Dusun Sidowayah, serta kurangnya dukungan dari berbagai pihak.
\end{abstract}

\section{Kata Kunci : Sidowayah, Kearifan, Lokal}

\section{A. Pendahuluan}


Kampung idiot merupakan sebutan lain bagi 3 desa yang ada di Kabupaten Ponorogo, yaitu Desa Sidoharjo di Kecamatan Jambon, serta Desa Karangpatihan dan Desa Pandak, keduanya di Kecamatan Balong yang sebagian masyarakatnya menyandang down syndrome (dikenal dengan keterbelakangan mental/idiot).

Keberadaan kampung idiot telah ada sejak 30 tahun lalu. Di antara ketiga desa tersebut, Desa Sidoharjo menjadi sorotan utama bagi banyak kalangan, karena menurut data grafis Heri (2011) dan paparan petugas puskesmas Sidoharjo, di desa tersebut terdapat 323 orang idiot yang terkumpul dalam satu dukuh bernama Sidowayah. Selain itu, di Desa Karangpatihan terdapat lebih dari 101 orang idiot tersebar di berbagai dukuh, dan di Desa Pandak terdapat 53 orang.

Salah satu daerah aliran sungai yang masih perlu perhatian khusus adalah daerah aliran sungai yang bermuara dari Gunung Rajek Wesi mengalir ke Dukuh Sidowayah, Desa Krebet Kecamatan Jambon dan Desa Pandak Kecamatan Balong. Hasil penelitian Fuad Fitriawan (2013) menyimpulkan "aliran sungai dan sumber mata air di tiga daerah tersebut tergolong aliran sungai dan sumber mata air berkualitas rendah, terutama Dukuh Sidowayah". Berdasarkan laporan penelitian Fitriawan ${ }^{1}$, indikator rendahnya kualitas aliran sungai dan sumber mata air di Dukuh Sidowayah yakni adanya kandungan logam berat yang melebihi ambang baku mutu sumber mata air, dan rendahnya kadar iodium, serta secara fisik air menjadi keruh di musim hujan, dan kering di awal musim kemarau, sehingga masyarakat di sekitar daerah tersebut kesulitan mendapatkan pasokan air bersih dan air untuk pengairan lahan pertanian. Permasalahan tersebut disebabkan salah satunya keadaan hutan yang telah lama gundul dan cenderung kurang terawat.

Saat ini beberapa kelompok pemuda yang peduli terhadap keadaan di Dukuh Sidowayah mencoba memberikan sebuah gambaran umum akan pentingnya lingkungan hidup. Gambaran umum itu diberikan melalui sebuah pendekatan bertajuk kearifan lokal terhadap lingkungan hidup, dengan tujuan mengembalikan ekosistem di daerah aliran sungai (DAS). Untuk itu, dicanangkanlah sejumlah program yang diharapkan kelak dapat dimanfaatkan oleh masyarakat secara berkelanjutan.

Adapu tujuan dari penelitian ini yaitu untuk mengetahui bentuk kearifan lokal masyarakat kampung idiot dalam upaya mengembalikan daerah aliran sungai dan sumber mata air di Dukuh Sidowayah Desa Sidoharjo Kecamatan Jambon Kabupaten Ponorogo. Mengetahui program kegiatan masyarakat dalam upaya mengembalikan daerah aliran

\footnotetext{
${ }^{1}$ Fuad Fitriawan, Kandungan Logam Berat Dan Kadar Yodium Pada Sumber Mata Air (Suatu Analisis Terhadap Faktor Terjadinya Down Syndrome Dengan Metode Atomic Absorbtion Spectrofotometry (AAS) Pada Masyarakat "Kampung Idiot" Sidowayah). Laporan Penelitian Dana Hibah DIKTIS 2012. 2013.
} 
sungai dan sumber mata air di Dukuh Sidowayah Desa Sidoharjo Kecamatan Jambon Kabupaten Ponorogo dan mengetahui kemanfaatan program kegiatan masyarakat sebagai bentuk kearifan local di Dukuh Sidowayah Desa Sidoharjo Kecamatan Jambon Kabupaten Ponorogo.

\section{B. Metodologi Penelitian}

Penelitian ini dilakukan dengan pendekatan observasi langsung di lapangan. Data yang dikumpulkan sebagian berbentuk angka-angka (khusus data sekunder), sedangkan data primer berbentuk kata-kata, peristiwa-peristiwa, gambar-gambar, dan catatan-catatan. Oleh karena itu, penelitian ini tergolong pada jenis penelitian kualitatif. Menurut Bogdan dan Taylor dalam bukunya Moleong ${ }^{2}$ penelitian kualitatif adalah penelitian yang menghasilkan data deskriptif berupa kata-kata tertulis atau lisan dari orang-orang dan perilaku yang dapat diamati.

Penelitian ini dilaksanakan di Dusun Sidowayah Desa Sidoharjo Kecamatan Jambon Kabupaten Ponorogo Provinsi Jawa Timur dengan sumber data yang diperoleh dari pemerintah Desa Sidoharjo, tokoh masyarakat, tokoh agama, tokoh pemuda, keadaan geografis dukuh, catatan-catatan dokumen di Kantor Desa maupun di Dukuh, dan beberapa elemen organisasi kemasyarakatan melalui beberapa teknik, yaitu observasi, wawancara, dan dokumentasi.

Teknik analisis data yang digunakan dalam penelitian ini adalah mengacu pada konsep Milles \& Huberman dalam bukunya Emzir $^{3}$ yaitu interactive model yang mengklasifikasikan analisis data dalam tiga langkah, sbb.:

\section{1) Reduksi Data (Data Reduction)}

Reduksi data yaitu suatu proses pemilahan, pemusatan perhatian pada penyederhanaan, pengabstrakan, dan transformasi data kasar yang muncul dari catatan-catatan tertulis di lapangan.

2) Penyajian Data (Display Data)

Data ini tersusun secara sistematis, sehingga memberikan kemungkinan adanya penarikan simpulan dan pengambilan tindakan secara runtut dan logis. Adapun bentuk lazim yang digunakan pada data kualitatif terdahulu yakni berbentuk teks naratif.

3) Pengecekan Keabsahan Temuan

\footnotetext{
${ }^{2}$ Moleong, Lexy J. Metodologi Penelitian Kualitatif. Pt. Remaja Rosda Karya. Bandung. 2010: 4

${ }^{3}$ Emzir. Metodologi Penelitian Kualitatif Analisis Data. Rajawali Press. Jakarta 2011:129-135
} 
Untuk menguji keabsahan temuan yang diperoleh dalam penelitian ini digunakan teknik triangulasi, dengan tujuan agar temuan tersebut benar-benar sesuai dengan tujuan dan maksud penelitian

\section{Bentuk Kearifan Lokal sebagai Bagian dari Konservasi SDA Masyarakat Dukuh Sidowayah}

Sidowayah adalah nama sebuah dusun yang dahulu berada di wilayah Desa Krebet Kecamatan Jambon Kabupaten Ponorogo Provinsi Jawa Timur. sekitar $23 \mathrm{~km}$ dari pusat Kota Reog Ponorogo. Berdasarkan keinginan dan tujuan yang sama dari masyarakat di wilayah yang lebih jauh dari Balai Desa Krebet, maka pada tahun 2006 Desa Krebet terpecah menjadi 2 (dua) desa, yaitu Desa Krebet dan Desa Sidoharjo. Saat itu Desa Sidoharjo masih berstatus definitif (perlu pendampingan).

Desa Krebet terbagi mejadi 5 kampung/dusun, sedangkan Desa Sidoharjo terbagi menjadi 3 kampung/dusun, yaitu Dusun Karang Sengon, Dusun Klitik, dan Dusun Sidowayah. Pada tahun 2008 Desa Sidoharjo diresmikan oleh Bupati Ponorogo, Muhadi Suyono. Jadi, sekarang Dusun Sidowayah bukan lagi bagian dari wilayah Desa Krebet, melainkan bagian dari wilayah Desa Sidoharjo.

Secara geografis Dusun Sidowayah terletak di bawah kaki Gunung Rajegwesi, arah barat daya kota reog Ponorogo, dengan batas-batas: sebelah selatan wilayah Kecamatan Bandar Watu Pathok Kabupaten Pacitan; sebelah timur wilayah Jonggol Kecamatan Jambon, dan Karang Patihan Kecamatan Balong; sebelah barat wilayah Dayakan Kecamatan Badegan; sedangkan sebelah utara wilayah Dusun Klithik dan Karang Sengon Sidoharjo.

Nama dusun "Sidowayah" muncul karena dahulu di daerah ini banyak tanaman bunga sidowayah. Wilayahnya termasuk dataran tinggi dan seluruhnya hampir dikelilingi gunung, struktur tanahnya tandus dan miskin kandungan yodium.

Penduduk Dusun Sidowayah saat ini telah mencapai lebih kurang 2727 jiwa ${ }^{4}$. Jumlah tersebut lebih banyak dibandingkan dengan jumlah penduduk dua dusun lain di Desa Sidoharjo.

Untuk menuju ke wilayah Dusun Sidowayah dibutuhkan waktu lebih kurang 4560 menit dari pusat kota reog Ponorogo, atau lebih kurang 20-30 menit dari kantor Kecamatan Jambon. Perjalanan kendaraan harus pelan karena jalannya masih berupa makadam, sehingga kendaraan hanya bisa berjalan dengan pelan.

\footnotetext{
${ }^{4}$ Data dari kepala dusun ( kamituwo )
} 
Sebagai wilayah yang masyarakatnya bekerja di bidang pertanian, sepengetahuan peneliti, persawahan di Sidowayah mulai tidak ada sekitar tahun 1996. Hal ini disebabkan oleh kecilnya aliran air irigasi karena dari tahun ke tahun volume air sungai terus menyusut akibat penggundulan hutan yang terus terjadi, serta rusaknya kalenan yang membutuhkan biaya tidak sedikit jika diperbaiki.

Lahan pertanian di Dusun Sidowayah berubah menjadi lahan kering, cocok ditanami jagung, kedelai, kacang tanah (brol), kacang hijau, kacang panjang, lombok, ketela, padi gogo, jeruk, jambu monyet, mangga, pisang, pepaya, terong, kol (dalam tahap uji coba). Sementara itu, hewan yang biasa diternak warga Dusun Sidowayah adalah sapi, kambing, ayam, dan mentok.

Dari segi kependudukan, masyarakat Dusun Sidowayah bersifat heterogen ${ }^{5}$ karena tidak sedikit warga yang tinggal di daerah ini bukan warga asli. Sebagian warga merupakan warga pendatang dari daerah lain, seperti Ngrandu, Balong, bahkan dari Kabupaten Wonogiri. Hal ini terjadi karena dahulu pada zaman larang pangan (sulit mencari makan) Dusun Sidowayah dianggap masih makmur, sehingga banyak orang datang dari luar dan menetap sebagai warga.

Forum Sidowayah Bangkit (FSB) merupakan forum besar yang dibentuk di Dusun Sidowayah pada tanggal 18 Agustus 2009, dengan beranggotakan 10 orang, meliputi PNS, tokoh masyarakat, tokoh agama, pemuda, perempuan, mahasiswa, dan perangkat desa. Tujuan organisasi ini menaungi atau menangani masalah orang-orang cacat dan idiot, serta masalah kemiskinan yang ada di Dusun Sidowayah. Saat ini, orang cacat berjumlah 150 orang dan warga miskin pada tahun 2010 berjumlah 604 KK.

Sebagai organisasi besar di sebuah dukuh, FSB mencakup dua buah organisasi, yaitu, Forum Sekolah Sangu Akik dan Forum Pesantren Rakyat Al-Hikmah.

Forum Sekolah Sangu Akik memiliki tujuan memberikan vasilitas pendidikan nonformal bagi para penduduk khususnya warga Dusun Sidowayah yang masih buta aksara. Sekolah Sangu Akik didirikan pada tahun 2010 oleh seorang pemuda bernama Jarot (almarhum) alias Mbah Kunting. Organisasi ini memiliki beberapa program yaitu pengenalan terhadap lingkungan hidup dalam bentuk pendidikan maupun praktik penanaman 1000 pohon di tahun 2011, 2012, dan 2013. Dalam program tersebut tergabung didalamnya siswa-siswa sekolah dasar hingga sekolah menengah atas di sekitar Kecamatan Jambon.

\footnotetext{
${ }^{5}$ Wawancara dengan salah satu warga, Jarot
} 
Berbeda dengan Forum Sekolah Sangu Akik, Forum Pesantren Rakyat AlHikmah memiliki. Sedikit berbeda dengan sebelumnya, Forum ini lebih banyak memiliki program diskusi berbagai bidang mulai amsalah keagamaan hingga permasalahan social yang dialami oleh masayrakat khususnya masyarakat Dusun Sidowayah.

Dari hasil wawancara dengan Sukarni pendiri Lembaga Pesantren Rakyat, "Dulu di kampung ini khususnya RT 3 sawah-sawah itu subur makmur, Mas, termasuk di musim kemarau, karena hutane masih ketel" (hutannya masih lebat). Dari ungkapan Sukarni diketahui adanya permasalahan ladang yang tidak dapat ditanami akibat tidak adanya stok air yang cukup untuk irigasi terutama di musim kemarau. lebih lanjut Sukarni mengatakan, "Itu di musim kemarau, Mas, kalau di musim hujan yang jadi masalah air minume Mas, buthek banyak lumpure” (air minumnya keruh dan berlumpur). Dijelaskan oleh Sukarni bahwa masalah besar di musim hujan adalah keruhnya air sumber untuk kebutuhan minum. Hal ini terjadi karena air sumber yang mengalir dari pegunungan ke aliran pipa-pipa maupun sungai senantiasa tercampur oleh lumpur pegunungan.

Lebih lanjut menurut Widadi, Kamituwo Dusun Sidowayah, sebenarnya masyarakat Dusun Sidowayah sangat mengharapkan tersedianya sumber mata air yang mencukupi baik di musim hujan maupun musim kemarau. Masyarakat memiliki harapan yang besar dari hasil pengolahan sawah dan ladang. Namun, masih menurut Kamituwo, keinginan warga akan adanya sumber air yang melimpah tidak terus didasari pada kesadaran akan pentingnya menjaga lingkungan hidup. Bahkan ada kebiasaan buruk bagi kebanyakan warga Sidowayah yang hingga saat ini masih dilakukan, yakni budaya "ubek alas" atau "sobo alas". Artinya mereka mengandalkan hasil hutan dengan menebangi kayu hutan, dahan, dan ranting, kemudian dijual agar menghasilkan uang untuk kebutuhan sehari-hari.

Bagi Kamituwo Widadi, jika warga menginginkan sumber daya air di Dusun Sidowayah kembali seperti dulu maka hal mendesak yang harus dan terlebih dahulu dilaksanakan adalah meningkatkan kualitas sumber daya manusia. Menurutnya mereka harus disadarkan agar memiliki kearifan lokal, sehingga dapat diajak berusaha keras mengembalikan sumber daya air melalui berbagai kegiatan. Untuk itu, di Dusun Sidowayah telah dirintis sejumlah program oleh organisasi masyarakat sebagai kearifan lokal.

\section{Program Kegiatan Masyarakat dalam Upaya Mengembalikan DAS dan Sumber Mata Air di Dusun Sidowayah}


Berikut ini dideskripsikan 3 program kegiatan yang telah dilaksanakan sebagai bentuk kearifan lokal di Dusun Sidowayah, meliputi program penghijauan, pipanisasi, dan pendidikan lingkungan hidup.

\section{a. Program Penghijauan}

Program penghijauan dirintis oleh Forum Sidowayah Bangkit, melalui lembaga Sekolah Sangu Akik bekerja sama dengan berbagai elemen masyarakat dan pemerintah, di antaranya Perhutani, Dinas pertanian (sebagai penyuplai benih), Sekolah Menegah, Perguruan Tinggi, LSM, dll. Program ini memiliki tujuan jangka panjang yaitu terkelolanya kembali lahan-lahan gundul dan lerenglereng gunung yang memiliki peranan penting dalam peresapan air. Pengelolaan lahan dan lereng gunung dimaksudkan agar dapat mencegah terjadinya erosi di musim hujan yang berdampak pada pendangkalan sungai dan sumber mata air.

Program penghijauan di Sidowayah dirintis pada tahun 2010, dan terealisasi pada tahun 2011. Menurut penjelasan Jarot, salah satu perintis program penghijauan, program ini diadakan dengan alasan dan tujuan yang luas, baik dari segi bagi amsyarakat, pelajar, hingga bagi keberlanjutan ekosistem lingkungan di Dusun Sidowayah. Lebih lanjut dikatakan bahwa kebutuhan air masyarakat Dusun Sidowayah sangat ditentukan oleh keberlanjutan hutan yang ada di Pegunungan sekitar Dusun Sidowayah. Namun, saat ini keberadaan hutan di sekitar Dusun Sidowayah sudah masuk kategori sangat memprihatinkan.

Alasan lain dirintisnya program penghijauan di Sidowayah, berdasarkan pengalaman peneliti selama mengikuti program tersebut sejak tahun 2012 hingga sekarang, bahwa ada sekitar 10 titik lahan yang memiliki kategori lahan gundul, sehingga dapat diperkirakan butuh waktu 20 tahun untuk mengembalikan lahan gundul tersebut menjadi lahan hijau.

Program penghijauan dilaksanakan pada bulan Desember hingga bulan Februari, atau saat musim hujan mulai datang hingga beberapa bulan ke depan. Program ini dilakukan di awal musim hujan dengan tujuan agar bibit yang ditanam benar-benar dapat tumbuh dengan baik dan bertahan hingga musim kemarau.

Pelaksanaan program penghijauan biasanya diawali dahulu dengan musyawarah antarpemuda dan beberapa perangkat dusun untuk membuat proposal bibit tanaman, kemudian diajukan ke instansi-instansi yang memungkinkan. Dinas Kehutanan Kabupaten Ponorogo merupakan instansi yang setiap tahun memberikan bantuan bibit tanaman. Dalam satu periode tahun biasanya kepada 
Dusun Sidowayah diberikan 5000 bibit tanaman dengan berbagai jenis, seperti tanaman trembesi, sengon, dll.

Ketika bibit tanaman telah terkumpul, Kasun membagi masyarakat menjadi sejumlah kelompok dan diberikan tugasnya masing-masing. Satu kelompok masyarakat bertugas membuat liang di beberapa titik lahan gundul, beberapa kelompok lain menjadi distributor bibit tanaman ke beberapa titik lahan yang sudah disiapkan, dan beberapa kelompok lainnya lagi bertugas menanam bibit yang sudah didstribusikan di setiap titik lahan.

Proses penanaman bibit oleh masyarakat di lahan Dusun Sidowayah dilakukan dalam beberapa gelombang. Dalam proses tersebut masyarakat dibantu oleh para relawan pelajar, mahasiswa, dan sejumlah LSM dari berbagai lembaga dan instansi, Mereka bersenang dan bersemangat bahu-membahu bersama kelompok masyarakat untuk menyelesaikan tugas yang telah dibagikan oleh Pak Kasun.

\section{b. Program Pipanisasi Sumber Mata Air}

Sumber daya air (SDA) adalah sumber kehidupan bagi manusia secara umum. Demikian juga di Dusun Sidowayah, sumber mata air menjadi sumber daya utama yang menentukan keberlangsungan hidup para warga di dusun tersebut. Oleh karena itu, Pak Kamituwo senantiasa mengingatkan warga bahwa keberadaan sumber daya air menjadi sangat penting untuk dijaga agar tetap ada. Selain melakukan penghijauan, salah satu cara untuk menjaga sumber daya air di Dusun Sidowayah adalah melakukan program pipanisasi sumber mata air.

Pipanisasi sumber mata air merupakan program yang bertujuan untuk menampung dan mengelola sumber mata air yang ada di Dusun Sidowayah agar pemanfaatan bagi warga dapat menjadi lebih mudah. Para warga tidak susah payah berjalan 4 sampai $5 \mathrm{~km}$ ke lokasi sumber mata air untuk mendapatkan air yang dibutuhkan sehari-hari.

Program pipanisasi di Dusun sidowayah mulai dilakukan secara swadaya pada tahun 1980-an, Pada saat itu masyarakat melakukan program swadaya secara gotong royong, dengan peralatan sederhana, dikomandani oleh Mbah Sarmin. Beliau adalah penjaga pipa-pipa penyaluran air yang menuju bak-bak penampungan air milik para warga. Kini Mbah Sarmin telah berhenti dari penjaga pipa karena sudah tua, kemudian digantikan oleh Pak Narji.

Program pipanisasi pada mulanya dilakukan hanya oleh para warga yang berdomisili di sekitar sumber mata air, dengan cara memasang bambu-bambu 
penyalur. Hal itu tidak memungkinkan bagi warga yang jauh dari sumber, sehingga mereka lebih mengandalkan sumur tradisional. Namun, ketika musim hujan tiba, sumur-sumur itu tidak lagi dapat mencukupi kebutuhan warga di Dusun sidowayah. Sementara itu, sumber mata air yang digunakan untuk pengairan di persawahan semakin berkurang. Hingga saat ini jika musim kemarau tiba, sebagian besar lahan di Dusun Sidowayah tidak dapat ditanami.

Pada tahun 1995 sebuah organisasi yang bergerak di bidang pemberdayaan dan perlindungan anak PLAN International memberikan sumbangsih sangat besar berupa program pipanisasi di seluruh titik sumber mata air di Dusun Sidowayah. Selain itu, juga dilakukan pembangunan tendon penampung air di beberapa titik di seluruh Dusun Sidowayah. Melalui program pipanisasi oleh PLAN Internasional telah diperoleh manfaat cukup besar bagi seluruh masyarakat Dusun Sidowayah. Hingga kini mereka sangat bergantung dengan adanya sumber mata air melalui pipanisasi dan tendon-tandon penampung air sumber.

Saat ini program pipanisasi dan penampungan air telah dikembangkan oleh PDAM Kabupaten Ponorogo di seluruh RT di Dusun Sidowayah. Pemetaan jumlah titik pipanisasi dan penampungan di setiap RT dapat dideskripsikan, sebagai berikut: RT 1 (1 titik), RT 2 (1 titik), RT 3 (1 titik), RT 4 (2 titik), RT 5 (2 titik), RT 6 (4 titik), RT 7 (1 titik), RT 8 (1 titik), RT 9 (1 titik), RT 10 (1 titik), RT 11 (1 titik), RT 12 (1 titik), RT 13 (2 titik). Pemetaan tersebut dapat diperiksa di lampiran.

Dampak positif dan negatif pipanisasi dan penampungan air di Dusun Sidowayah. Dampak positifnya yakni terkelolanya sumber mata air, sehingga dapat dimanfaatkan oleh seluruh warga. Namun, dampak negatifnya hingga saat ini warga terlalu ketergantungan dengan adanya sumber mata air tersebut. Maksudnya jika suatu saat sumber mata air itu kering maka akan memberikan dampak negatif pada berbagai sektor. Dampak negatif lainnya yakni tidak baiknya manajemen pemeliharaan pipanisasi, misalnya ketika terdapat pipa-pipa yang mengalami kerusakan tidak dapat segera tertangani, sehingga dapat menghambat aliran air ke penampungan.

Dampak negatif pipanisasi saat ini telah dirasakan oleh warga masyarakat, antara lain akibat mengeringnya salah satu sumber mata air, sehingga beberapa sektor pertanian tidak dapat diolah oleh warga, akibatnya pendapatan mereka berkurang. Untuk itu, beberapa warga harus memanfaatkan kayu hutan untuk dijual demi mencukupi kebutuhan mereka sehari-hari. 


\section{c. Pendidikan Lingkungan Hidup}

Begitu pentingnya sumber daya air bagi kelangsungan hidup warga Dusun sidowayah, usaha yang dilakukan para pemuda Sidowayah tidak cukup hanya pada tataran praktis saja, namun pada tataran teoritis sebagai bentuk pendidikan dan pemahaman akan pentingnya sumber daya alam khususnya bagi para generasi muda dengan sebuah program yang disebut dengan pendidikan Lingkungan Hidup.

Forum Sidowayah bangkit menunjuk dua lembaga masyarakat yang dianggap mampu menjalankan program Pendidikan Lingkungan Hidup yaitu lembaga Sekolah Sangu Akik dan Pesantren Rakyat. Program ini dimulai sejak tahun 2010, dengan sejumlah program pendidikan, di antaranya: (1) Sarasehan 3 Bulanan, (2) Temu Pakar Lingkungan Hidup, (3) Pembinaan Sekolah Formal, dan (4) Pendampingan Sekolah Wiyata Mandala (Adi Wiyata).

Program (1) Sarasehan 3 Bulanan, dilakukan dengan tujuan untuk mempererat tali silaturahmi bagi warga masyarakat Dusun Sidowayah. Dalam sarasehan tersebut berkumpul juga warga dari berbagai elemen masyarakat lain, seperti lembaga-lembaga keagamaan, Ansor, LSM, hingga mahasiswa dari berbagai kampus di Jawa Timur.

Grand tema pembahasan dalam sarasehan selalu dikaitkan dengan wawasan lingkungan hidup, berorientasi pada berbagai bidang ilmu keagmaan, sosial, budaya, kultural, dan ekonomi. Dari pertemuan 3 bulanan itu biasanya muncul ide-ide baru yang kemudian menjadi program-program strategis untuk disepakati dan dilaksanakan bersama, seperti penghijauan, pendampingan sekolah wiyata mandala, dll.

Program (2) Temu Pakar, dilaksanakan secara kondisional, yakni dalam waktu yang disesuaikan dengan situasi, dengan berbagai tema pokok pembahasan. Pakar yang diundang dalam program ini desesuaikan dengan kondisi pakar.

Program (3) Pembinaan Sekolah Formal, biasanya dilakukan oleh para pemuda Sidowayah yang tergabung dalam Komunitas Lestari Alamku (KLA). Komunitas ini merupakan salah satu progam strategis yang dilakukan oleh para anggota dalam pendampingan sekolah formal dalam rangka mewujudkan sekolah adiwiyata. Pendampingan ini dilakukan terhadap sejumlah sekolah formal, di antaranya SDN 2 dan SDN 3 Sidoharjo, SMPN Jambon, SMK Badegan, SMKN Jenangan, dan MAN 1 Ponorogo. 


\section{E. Sifat Ketergantungan sebagai Penyebab Rendahnya Kemandirian Warga}

\section{Kampung Idiot}

Berdasarkan hasil penelitian Fuad Fitriawan $(2013)^{6}$, total warga penderita down syndrome di tiga kawasan perkampungan di Kabupaten Ponorogo mencapai 445 orang. Mereka terdapat di sejumlah desa, di antaranya: (1) di Desa Sidoharjo Kecamatan Jambon terdapat 323 orang, (2) Desa Karangpatihan Kecamatan Balong 69 orang, dan (3) Desa Pandak Kecamatan Balong 53 orang. Warga down syndrome di ketiga desa tersebut seluruhnya tumbuh secara tidak normal dan miskin. Dengan demikian, pertumbuhan tidak normal dan miskin di Kabupaten Ponorogo paling banyak terdapat di Desa Sidoharjo Kecamatan Jambon, yakni 323 orang (5,7\% dari 5.690 jiwa penduduk normal Desa Sidoharjo, atau lebih kurang 1\% dari 38.998 jiwa penduduk Kecamatan Jambon).

Karakteristik tiga desa wilayah warga down syndrome di Kabupaten Ponorogo dapat dikategorikan satu tipikal, yakni sama-sama berada di lereng gunung, tanah berkapur yang sulit ditanami, terpencil, akses transportasi sulit, makanan pokok tiwul (olahan dari singkong), miskin, berpendidikan rendah, dan pekerjaan mayoritas buruh tani. Tiga wilayah tersebut juga memiliki ciri khas lain, yakni hanya memiliki satu akses jalan masuk, dengan sisi-sisi jalan tertutup hutan dan perbukitan. Oleh karena itu, akses menuju ke tiga wilayah tersebut sangat tidak mudah. Setidaknya diperlukan satu dua jam perjalanan dari pusat Kota Ponorogo dengan kendaraan roda empat.

Dukuh Sidowayah di Desa Sidoharjo merupakan daerah paling sulit diakses oleh pendatang, karena hanya ada satu jalan utama setelah melewati sawah-sawah dan hutan, bahkan jalan sangat sempit setelah memasuki desa tersebut. Umumnya jalanan terbagi tiga tipe, yakni jalan beraspal, jalan makadam, dan jalan tanah, dengan berbagai tanjakan dan turunan khas daerah pegunungan. Pendatang yang baru pertama berkunjung, tidak berlebihan jika menyamakan akses masuk ke Sidowayah mirip dengan film-film horor di Indonesia. Sepi, banyak pohon menjulang tinggi, penerangan rumah minim, terutama di malam hari, dan jalan sempit, serta banyak kelokan yang membingungkan. Jadi, akses menuju Dukuh Sidowayah Desa Sidoharjo dapat dikatakan paling berat daripada dua desa lainnya di Kecamatan Balong yang sama-sama memiliki warga down syndrome.

Demikian banyak penderita down syndrome (keterbelakangan mental) di Dukuh Sidowayah, ternyata warga pada umumnya tidak lagi mempermasalahkan mereka.

\footnotetext{
${ }^{6}$ Fuad Fitriawan, Kandungan Logam Berat Dan Kadar Yodium Pada Sumber Mata Air (Suatu Analisis Terhadap Faktor Terjadinya Down Syndrome Dengan Metode Atomic Absorbtion Spectrofotometry (AAS) Pada Masyarakat "Kampung Idiot” Sidowayah). Laporan Penelitian Dana Hibah DIKTIS 2012/2013.
} 
Menurut keterangan Pak Parnu, Kades Sidoharjo, "Mereka bukan masalah bagi kami, sebab para warga normal sudah nrima (menerima) keadaan.” Pola interaksi warga down syndrome juga tidak jauh berbeda dengan kehidupan manusia normal. Bahkan, penderita keterbelakangan mental yang bisa bekerja pun diarahkan untuk membantu orang tua. Sebaliknya, meski tidak mampu diajari apa pun dan berkeliaran di perkampungan, mereka dibiarkan begitu saja, karena tidak ada satu pun yang bertipe menyerang, dan warga juga tidak pernah merasa terganggu.

Sisi perekonomian warga di Dukuh Sidowayah jelas tidak dapat dibanggakan. Sebagai buruh tani, penghasilan mereka lebih kurang 100-300 ribu rupiah per bulan. Dengan rendahnya penghasilan keluarga, ditambah dengan jumlah anggota keluarga (rata-rata beranak lebih dari dua), maka ujung-ujungnya warga tidak mampu mengonsumsi makanan bergizi secara rutin. Menurut keterangan Kades yang paling banyak memiliki warga penderita down syndrome, warganya hanya bisa menikmati nasi saat pembagian beras untuk keluarga miskin (raskin). Namun, beras jatah dari pemerintah itu hanya bisa dikonsumsi beberapa hari. Setelah itu, kembali lagi mereka mengonsumsi tiwul. "Biasanya tanpa lauk. Tiwul itu saja makanannya," ucap Kades Parnu.

Dukuh Sidowayah Desa Sidoharjo Kecamatan Jambon memang termasuk kawasan yang sangat miskin. Belakangan dukuh itu kerap didatangi tamu yang penasaran dengan label kampung down syndrome di kawasan tersebut. Jawa Pos ketika berjumpa dengan beberapa orang dari luar Ponorogo, menyatakan sengaja datang ke Sidowayah karena penasaran. Namun, banyaknya tamu yang berdatangan ternyata direspons dengan sikap warga yang semakin berani untuk meminta imbalan. Hal itu dibenarkan oleh Kamituwo Sidowayah pada saat peneliti sedang bersilaturahmi ke rumahnya.

"Mereka menjadi bergantung terhadap bantuan,” terang Indadi. Bukan hanya uang yang menjadi sasaran penduduk desa. Kondisi down syndrome yang dialami beberapa warga itu juga menjadi senjata untuk menarik bantuan dari pemerintah. Tidak hentihentinya bantuan dikucurkan untuk warga desa tersebut, seperti garam beryodium, beras, bahkan ternak. Sayang, tujuan bantuan yakni mengentaskan dan membuat warga desa berdikari, tetapi sebhaliknya malah sepertinya tidak akan tercapai. Para penduduk seolah telanjur terbiasa meminta barang kepada para pengunjung. Alih-alih memberdayakan diri dengan memanfaatkan bantuan, mereka justru lebih memilih menggantungkan diri pada pendapatan dari para pengunjung.

"Itu yang harus diubah. Pemerintah harus memberikan bantuan yang sifatnya memancing mereka untuk berdaya," tegas Indadi. Memang, selama ini bantuan yang diberikan tergolong instan. Warga menerima dan menikmati bantuan, lalu habis, dan 
mereka menanti bantuan lagi. Pemberdayaan itu juga yang diharapkan oleh Kades Sidoharjo. "Percuma kalau hanya terus diberi makan," ungkapnya.

\section{F. Permasalahan-permasalahan yang Menjadi Penyebab Kurang Efektivitas Program Forum Sidowayah Bangkit}

Tiga program yang diusung oleh Forum Sidowayah Bangkit melalui penghijauan, pipanisasi, dan pendidikan lingkungan hidup pada dasarnya memiliki rencana strategi, bahkan publikasi melalui forum-forum desa telah dilakukan oleh mereka. Namun, lagilagi kondisi masyarakat yang ada di Dusun Sidowayah justru menjadi kendala dalam menyukseskan program-program tersebut. Ada sejumlah kendala yang menjadi penyebab rendahnya capaian target program Sidowayah bangkit, sbb.:

1. Perilaku sobo alas masih banyak dilakuan oleh warga Dukuh Sidowayah. Perilaku ini menjadi kendala utama yang menyebabkan rendahnya capaian program penghijauan. Perilaku sobo alas merupakan perilaku warga dalam bentuk perjalanan ke hutan atau bukit-bukit pegunungan di Dusun Sidowayah selama berhari-hari, dengan tujuan mencari kayu-kayu besar kecil beserta ranting-rantingnya yang dapat dijual untuk memenuhi kebutuhan sehari-hari, termasuk sebagai bahan bakar. Perilaku ini sangat sulit diubah, kondisi ekonomi yang kurang, serta lahan sawah yang tidak bisa diandalkan utamanya ketika musim kemarau datang, menjadi alasan yang tak terbantahkan untuk tidak meninggalkan kebiasaan sobo alas. Kondisi ini menjadi sebuah ironi di tengah-tengah sebagian warga yang telah bertahun-tahun menjalankan program penghijauan untuk memulihkan daerah aliran sungai, namun hanya untuk menyediakan sumber pangan atau kayu bagi sebagian warga yang lain.

2. Kurangnya sokongan dana dari masyarakat menyebabkan terganjalnya biaya akomodasi kegiatan penghijauan maupun perawatan pipa-pipa yang telah lama terpasang. Pada akhirnya juga diperlukan biaya perawatan untuk mengganti pipa yang rusak, namun pipa-pipa rusak itu sebagian dibiarkan begitu saja, akibatnya terhambatlah subsidi air dari sumber mata air di beberapa titik.

3. Kebiasaan terlalu sering menerima subsidi bantuan dari berbagai kalangan instansi pemerintah dan lembaga penyandang dana juga menjadikan sebagian warga selalu menanti-nanti datangnya subsidi, baik dari pemerintah maupun swasta, sehingga di kala subsidi itu tidak datang maka mereka akan lebih sulit untuk bangkit dari keadaan tersebut.

4. Terbatasnya sumber daya manusia internal yang mumpuni juga menjadi kendala. Keadaan warga yang menyandang cacat mental itu diakui atau tidak juga memberikan 
pengaruh terhadap sumber daya manusia. Mereka yang menderita down syndrome juga memerlukan perhatian khusus utamanya oleh tetangga dan pamong desa. Dengan demikian sedikit banyak para tetangga dan pamong disibukkan oleh kegiatan untuk mengawasi dan merawat warga down syndrome. Pernah suatu ketika Kasun Indadi bercerita, "Kalau di sini itu gampang-gampang susah, Mas! Kalau mau menerapkan program penghijauan itu butuh waktu dan tenaga ekstra. Padahal program telah kita rancang dengan matang, tetapi belum bisa dilaksanakan dengan maksimal, lha gimana lagi, wong saya itu juga jadi kasun, selain itu saya juga nyambi jadi juru shoting. Di samping dua pekerjaan itu saya juga memiliki tanggung jawab njaga warga yang idiot walaupun kadang saya juga minta bantuan tetangga mereka untuk setiap hari ngasih beras 1 cangkir bergilir, supaya dimasak biar ndak kelaperan yang idiot tadi. Pernah, Mas, suatu ketika ada salah seorang warga idiot, namanya Mbah Kunting. Ia hidup sebatang kara karena semua keluarganya sudah meninggal, dan seperti biasanya tetangga yang agak mampu mau menyuplai beras/nasi buat dia. Dan suatu ketika saya pas lagi sibuk dan selama 3 hari ndak kontrol subsidi giliran memberi makanan buat si Boimin, dan ternyata dugaan saya benar kalau selama 2 hari dia ndak dikasih makan. Lalu saya tanya, makan apa, mbah? Jawabannya, Makan kucing, Mas". Begitulah salah satu gambaran tragis kehidupan masyarakat yang menyandang down syndrome.

5. Kendala terakhir adalah banyaknya warga dusun dan para pemuda melancong dan tidak kembali lagi ke Dusun Sidowayah. Kendala ini menjadi sangat vital ketika si pelancong telah diakui warga bahwa memiliki potensi besar dan pernah menjadi motor penggerak kegiatan masyarakat. Di saat penggerak motor penggerak itu pergi, nyaris kegiatan yang telah dirintis itu menjadi lesu dan tersedat. Walaupun demikian kadang masih ada usaha dari para warga lain untuk tetap menghidupkan kebudayaan dan kegiatan itu agar sedikit nampak berjalan. Selain itu juga nampak kesan bahwa jika suatu waktu ada pendatang baru, yang sekiranya singgah beberapa waktu, maka kegiatan-kegiatan tersebut akan nampak hidup kembali. Atau ketika subsidi bantuan datang maka kegiatan-kegiatan, misalnya penghijauan akan nampak hidup kembali. Sebaliknya ketika telah habis masa waktunya maka kondisinya kembali ke awal biasanya, seperti ketika semua itu tidak ada.

\section{G. SIMPULAN}

Bentuk kearifan lokal di Dusun Sidowayah dalam upaya mengembalikan Daerah Aliran Sungai dan Sumber Mata Air lebih banyak dilakukan dalam kegiatan kemasyarakatan yang diorganisasikan oleh satu organisasi pemuda yaitu Forum Sidowayah Bangkit.Program kegiatan masyarakat sebagai bentuk kearifan lokal dalam 
upaya mengembalikan Daerah Aliran Sungai dan Sumber Mata Air di Dusun Sidowayah di antaranya berupa Program Penghijauan, Program Pipanisasi, dan Program Pendidikan Lingkungan Hidup. Belum terlihatnya kemanfaatan program dari Forum Sidowayah Bangkit khususnya untuk masyarakat Sidowayah disebabkan beberapa faktor kendala, yakni adanya perilaku atau kebiasaan kurang baik warga Dusun Sidowayah, serta kurangnya dukungan dari berbagai pihak.

\section{H. DAFTAR PUSTAKA}

Apriyanto, Y. dkk. (2008). Kearifan Lokal dalam Mewujudkan Pengelolaan Sumberdaya Air yang Berkelanjutan. Makalah Pada PKM IPB, Bogor.

Damayanti. 2010. Kebijakan Pembangunan Wilayah Berbasis Pengelolaan DAS Terpadu dan Berkelanjutan. Bogor [ID]: Institut Pertanian Bogor

Effendi E. 2008. KajianModel Pengelolaan Daerah Aliran Sungai (DAS) Terpadu. Jakarta: Direktorat Kehutanan dan Konservasi Sumberdaya Air, Badan

Emzir. 2011. Metodologi Penelitian Kualitatif Analisis Data. Jakarta: Rajawali Press.

Fitriawan. Fuad. Kandungan Logam Berat Dan Kadar Yodium Pada Sumber Mata Air (Suatu Analisis Terhadap Faktor Terjadinya Down Syndrome Dengan Metode Atomic Absorbtion Spectrofotometry (AAS) Pada Masyarakat "Kampung Idiot” Sidowayah). 2013. Laporan Penelitian Hibah Ditpertais.

Sudiarsa, I Wayan. 2004. Air Untuk Masa Depan. Jakarta: PT. Rieneka Cipta

Kartodiharjo, Murtilaksono, Sudadi. 2004. Institusi Pengelolaan Daerah Aliran Sungai: Konsep dan Pengantar Analisis Kebijakan. Bogor [ID]. Institut Pertanian Bogor

Kepmenkes RI No. 907/MENKES/SK/VII/2002 tentang Syarat-syarat dan Pengawasan Kualitas Air Minum. 2002. Jakarta

Keraf, A.S. (2010). Etika Lingkungan Hidup. Jakarta: Penerbit Buku Kompas

Kurniyanto. 2011. Strategi Pengembangan Kelembagaan Kegiatan Rehabilitasi Hutan dan Lahan Partisipatif (RHLP) di DAS Cikundul Kabupaten Cianjur. [Tesis tidak dipublikasikan]. Bogor [ID]: Institut Pertanian Bogor

Koentjaraningrat, 1986. Pengantar Ilmu Antropologi. Cetakan ke-6. Jakarta: Aksara Baru.

Moleong, Lexy J. 2010. Metodologi Penelitian Kualitatif. Pt. Remaja Rosda Karya. Bandung.

Nuddin. 2007. Analisis Sistem Kelembagaan dalam Perencanaan dan Strategi Pengelolaan Lahan Kritis DAS Bila. [Disertasi tidak dipublikasikan]. Bogor [ID]: Institut Pertanian Bogor

Peraturan Pemerintah RI No 38 tentang Sungai Pasal 3. 
Ridwan, N.A. (2007). Landasan Keilmuan Kearifan Lokal. Jurnal Studi Islam dan Budaya. Vol.5, (1), 27-38.

Rismunandar. 2001. Air Fungsi dan Kegunaannya Bagi Pertanian. Bandung : Sinar Baru Algaesindo.

Sirang. 2011. Kajian Potensi Ketersediaan Air di Daerah Aliran Sungai Sebelimbing Kabupaten Kotabaru. Jurnal Hutan Tropis [Internet]. [dikutip 13 September 2013]. 12(32). Dapat diunduh: ejournal.unlam.ac.id/index.php/jht/article/view/350/308

Sinukaban. 2008. Pembangunan Daerah Berbasis Strategi Pengelolaan Daerah Aliran Sungai. Bogor [ID]: Institut Pertanian Bogor

Undang-undang Republik Indonesia Nomor 7 Tahun 2004 tentang Sumberdaya Air. Jakarta.

Bakker. 2009. Transboundary River Floods and Institutional capacity. Dalam: Journal of the American Water Resources Association. [internet]. [dikutip 09 November 2012]; 45(3):553-566 dapat diunduh: http://web.ebscohost.com/ehost/pdfviewer?sid=e93d5242-ecb9-4812-965b0662cf983aaf\%40sessionmger12\&vid=1\&hid=15

Http://filsafat.ugm.ac.id (Diakses tanggal 30 April 2010) 